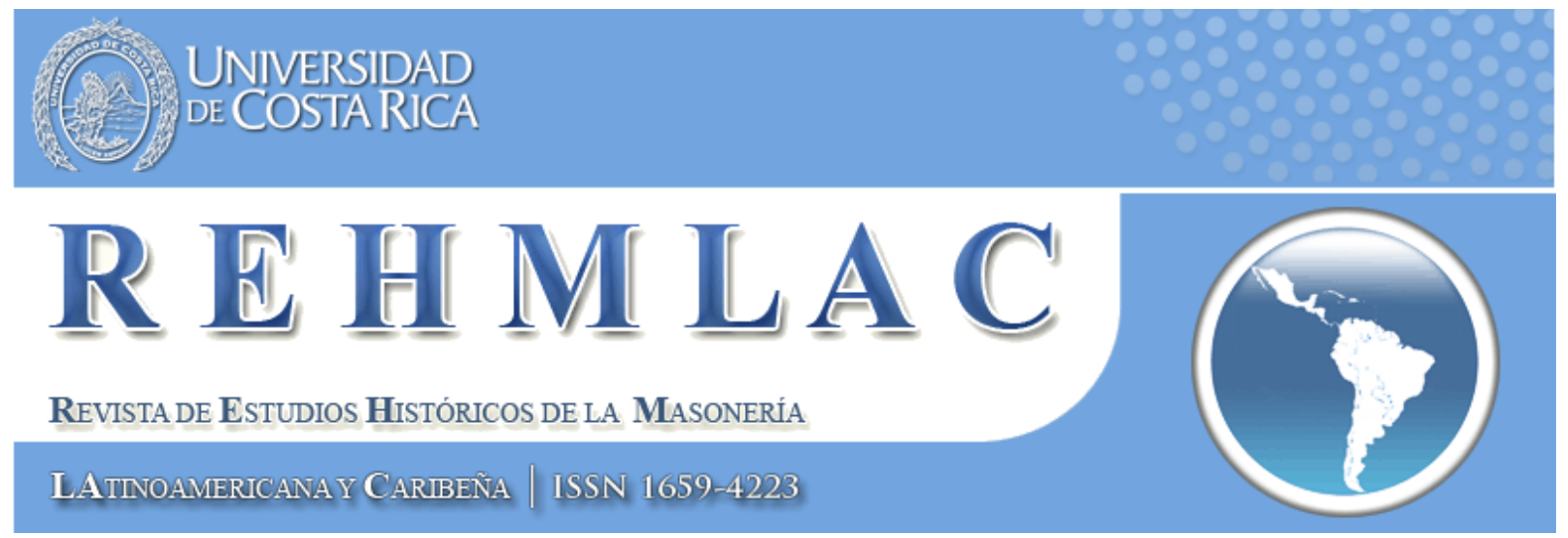

David Vergauwen

"'Où peut-on être mieux?' Masonic music and musicians in $19^{\text {th }}$-century Brussels"

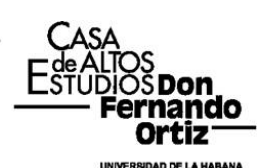


(C) David Vergauwen and REHMLAC.

\section{REHMLAC team}

Academic Committee:

Miguel Guzmán-Stein (Universidad de Costa Rica, Costa Rica)

José Antonio Ferrer Benimeli (Universidad de Zaragoza, España)

Margaret Jacob (University of California Los Angeles, United States)

Eduardo Torres Cuevas (Universidad de La Habana, Cuba)

María Eugenia Vázquez Semadeni (Stanford University, United States)

Éric Saunier (Université du Havre, France)

Andreas Önnerfors (Lunds universitet, Sverige)

Samuel Sánchez Gálvez (Universidad Carlos Rafael Rodríguez de Cienfuegos, Cuba)

Roberto Valdés Valle (Universidad Centroamericana “José Simeón Cañas”, El Salvador)

Céline Sala (Université de Perpignan, France)

Dominique Soucy (Université de Franche-Comté, France)

Guillermo de los Reyes Heredia (University of Houston, United States)

Dévrig Mollès (Université de Strasbourg, France)

Felipe Santiago del Solar Guajardo (Universidad ARCIS, Santiago de Chile)

Carlos Francisco Martínez Moreno (Universidad Nacional Autónoma de México, México)

Michel Goulart da Silva (Universidade do Estado de Santa Catarina, Brasil)

Reviewers of style:

Sylvia Hottinger (Centro de Estudios Históricos de la Masonería Española, España)

Kyle Jackson (University of California Los Angeles, United States)

Webmaster:

Luis Martín Valverde Alfaro (Universidad de Costa Rica, Costa Rica)

Editor:

Yván Pozuelo Andrés (IES Universidad Laboral de Gijón, España)

Correo electrónico: yvan@edu.xunta.es

Director:

Ricardo Martínez Esquivel (Universidad de Costa Rica, Costa Rica)

Correo electrónico: ricardo.martinezesquivel@ucr.ac.cr

Web: rehmlac.com/

E-mail: info@rehmlac.com

P.O.B.: 243-2300 San José, Costa Rica 


\section{Cited in:}

Academia.edu

Aladin. WRLC. Libraries Catalog

AFEHC. Asociación para el Fomento de los Estudios Históricos en Centroamerica

Biblioteca de Georgetown

CRICCAL, Université Sorbonne Nouvelle Paris 3

CERGE EI. Portál elektronických časopisů. Univerzita Karlova v Praze Departamento de Filosofía de la Universidad Centroamericana "José Simeón Cañas"

Dialnet, Universidad de la Rioja

Directorio y recolector de recursos digitales del Ministerio de Cultura de España

DOAJ. Directory of Open Access Journals

e-revist@s. Plataforma Open Access de Revistas Científicas Electrónicas

Freemasonry and Civil Society Program at UCLA

Fudan University Library Academic Resource Portal

Google académico

Institute for the Study of the Americas at University of London

Latindex (UNAM)

Latindex.ucr. Repositorio de revistas de la Universidad de Costa Rica

Library Catalogue of University of South Australia

Museo Virtual de la Historia de la Masonería de La UNED

Nuevo Mundo. Mundos Nuevos

REDIAL. Red Europea de Información y Documentación sobre America Latina

SciELO - Scientific Electronic Library Online

Sherpa/Romeo

SID. Sistema Integrado de Documentación. Universidad Nacional de Cuyo

Toronto Public Library

UBO. Revues en ligne. Université de Bretagne Occidentale

Universia. Biblioteca de Recursos

University of Saskatchewan Library

University of Wiscosin-Madison Libraries

Western Theological Seminary. Beardslee Library Journals 


\section{"'Où peut-on être mieux?' Masonic music and musicians in $19^{\text {th }}$-century Brussels"}

David Vergauwen

Doctor in History, Free University of Brussels-VUB, Belgium, 2014. Member of the Interdisciplinary Research Group Freemasonry-VUB.

E-mail: davidvergauwen@yahoo.com

The researcher David Vergauwen has defended a PhD-thesis, entitled "'Où peut-on être mieux?' Masonic music and musicians in $19^{\text {th }}$-century Brussels" at the Free University of Brussels (VUB) in Belgium the $21^{\text {st }}$ of May 2014.

David Vergauwen born in 1978 in Belgium.

The author has granted us the following interview.

\section{What were the reasons that led you to focus your research on Freemasonry?}

Finding a suitable subject for my $\mathrm{PhD}$-thesis was actually not that hard. I already did a degree in history as well as musicology and I noticed that next to nothing had been published on Belgian masonic music and musicians. My supervisor, Prof. dr. Jeffrey Tyssens was quick to point out to me that source material was scarce in relation to $18^{\text {th }}$-century masonic music, but that there was a whole that needed to be done on the $19^{\text {th }}$ and $20^{\text {th }}$ century. Thanks to his guidance, I was able to locate the necessary sources and to start working.

\section{What were the sources you used?}

The source material turned out to be quite diverse: I have worked on masonic sources on the one hand and non-masonic sources on the other.

Masonic sources are to be found at the so called Moskou Archive that can be accessed by way of the CEDOM/MADOC study Centre in Brussels. They boast a substantial archive, very rich in detail information. Next to the Moskou Archive, it was vital to collect information in the archives of two main lodges in Brussels who are still active today.

The non-masonic source material was found at the archives of the Brussels Conservatory, the Royal theatre of 'la Monnaie', the main theatre of the city, the Belgian academy of sciences and letters, the archives of the city of Brussels and so on.

\section{What were the main difficulties you encountered? How did you surmount them?}

What bothered me the most was the unwillingness of one particular lodge in Brussels to grant me direct access to their archive. I have written, called, showed up in person and applied 
pressure wherever I could, but this one lodge could not be brought to action. This was particularly frustrating, since I expect there to be documents that would provide valuable clues to questions that remain as yet unanswered.

I do believe that most masonic organizations implement a very open policy of wanting to provide access to scholars wanting to study the history of the fraternity, but as I was able to experience, not every lodge is willing to co-operate.

\section{What major historical problems has your work resolved?}

As the selection of the source material already made apparent, I was very much interested in the connections of these musicians with freemasonry on the one hand and society on the other. So I tried to make as many connections as I possibly could between the various institutions where these individuals worked and studied and their masonic affiliations. Only by doing so was I able to answer questions like: how professional were those freemasons who played during lodge meetings, what was their social status, where did they come from and what did they do?

I think this sociological analysis is surely one of the most interesting topics of the thesis.

\section{Please, could you summarize the essence of your thesis in two lines?}

My thesis looked at masonic musicians, their music and their social position in Brussels during the $19^{\text {th }}$ century. They turned out to be highly educated and their music turned out to be very diverse, ranging from masonic songs (chansons) to fully orchestrated cantatas. Also noteworthy was their social rise during the whole $19^{\text {th }}$ century.

\section{Now, what are your professional plans?}

I am planning on doing some more research on issues that captured my attention during the $\mathrm{PhD}$, but for which I have had no time yet.

\section{Would you like to highlight an aspect that has not been covered and you consider worthy of review?}

I very much enjoy the work outside the academic world as well. At the moment I am preparing my thesis for publication, but I won't leave it at that. I am also working on an exhibition at the Museum of Belgian Freemasonry in Brussels that will take place from march until august. Since a musicologist cannot rest before he has put some musicians at work, I have also tried to get the music I discovered performed and registered. I am pleased to say that two concerts will take place in Antwerp: one on Sunday 1 February which consists of songs and a funeral cantata and another on Sunday 22 February, which will bring to live the large masonic cantata for orchestra, soloists and choir, writing for the first king of the 
Belgians, Leopold I, in combination with Mozart's masonic cantatas.

People who want to learn more about the exhibition or the concerts can contact me on: davidvergauwen@yahoo.com

This interview was done Monday 8 Augustus 2014.

Authors of the Interview: Ricardo Martinez Esquivel and Yván Pozuelo Andrés, Director and Editor REHMLAC. 